\title{
Discussion on the Deficiencies and Perfection of Subparagraph 1(6) of Article 35 of Tax Administration Law
}

\author{
Gao Guilin \\ School of Law professor, Capital University of Economics \\ and Business in Beijing, China \\ gaoguilinrenda@163.com
}

\author{
Han Yuyu* \\ School of Law student, Capital University of Economics \\ and Business in Beijing, China \\ hyy55355@163.com
}

\begin{abstract}
This paper carries out a summary and an analysis by studying ten cases that suitable to subparagraph 1 (6) of article 35 in Tax Administration Law with the empirical analysis method, and finds that tax authorities have different basis of identifying the price to be obviously lower in term of different cases in different regions, the percentage of declared taxable value in market transaction average price ranges from $44 \%$ to $90.6 \%$, and a lack of definition of "being lower obviously" leads to a big gap between the asserting standards of different tax authorities. China fails to specify the procedures and methods to fix the taxable price for tax authorities, which can easily lead to their abuse of discretion power. This paper considers that it is very necessary to carry out a clear definition of "being lower obviously" and "being without of due causes", and proposes suggestions that legislation Tax Administration Law should borrow from article 19 of Interpretation II on Contact Law when a taxpayer considers the taxable price approved by the tax authority is unreasonable, the evidences provided by the taxpayer will be verified by the third-party authority in case tax authorities abuse their discretionary power.
\end{abstract}

Keywords-Tax Administration Law; Being obviously lower; Without due causes; Article 19 of Interpretation II on Contact Law

\section{INTRODUCTION}

In the first case of tax administrative procedure by the Supreme Court, Defa Case, Defa Company sold its housing estates by auction for 113 million yuan. The First Inspection Bureau of Guangzhou Local Taxation Bureau checks and ratifies the market transaction price should be 311.678775 million yuan through viewing the transaction price cases of the estates surrounding Defa's authorized for auction. According to the regulations of subparagraph 1 (6) of article 35 of Tax Administration Law, the First Inspection Bureau of Guangzhou Local Taxation Bureau considers Defa Company sells its partial housing estates at a price obviously lower than the market average level without due causes, and requires Defa Company to make a supplementary payment for turnover tax and embankment protection cost according to the market price approved by the tax authority. Defa Company thinks its transaction behaviors follow the market rule, the tax authority has no rights to control the transaction price, and the tax authority lacks sufficient evidence in considering Defa Company's declared taxable price is obviously lower and lacks due causes. The dispute between Defa Company and the tax authority makes the controversies over "being without due causes" and "being obviously lower" of subparagraph 1 (6) of article 35 of Tax Administration Law among all sectors of society emerge one after another. That what is being obviously lower and what is without due causes has not be defined clearly in Chinese law of tax.

\section{StATISTICS AND ANALYSIS OF "BeING OBVIOUSLY LOWER" IN A CASE}

If taxpayers' declared tax amount is lower than the average market transaction price, but not obvious, the tax authority has no rights to check and ratify the tax amount payable, or it checks and ratifies the tax amount payable according to the ratio of taxpayers' declared tax amount and average market transaction price. However, Chinese law has not made clear definition of "being obvious" and the corresponding accurate ratio. In order to further learn the situation on the application and practices of subparagraph 1 (6) of article 35 of Tax Administration Law in specific cases, this paper selects ten cases and respectively carries out summary and statistics on the assertion of "being obviously lower" and "being without due causes". The relevant content is shown in the following table 1 and 2: 
TABLE I. STATISTICS ON "Being Obvious Low"

\begin{tabular}{|c|c|c|c|c|}
\hline Cases & $\begin{array}{l}\text { The Price Approved by the } \\
\text { Tax Authority }\end{array}$ & Transaction Price & $\begin{array}{l}\text { Ratio of Transaction Price } \\
\text { and Average Market Price }\end{array}$ & Judgement Reason \\
\hline $\begin{array}{l}\text { Guangzhou Defa } \\
\text { Case }\end{array}$ & 311.678775 million yuan & 138.255 million yuan & $44.3 \%$ & $\begin{array}{l}\text { The taxpayer pays back taxes: The average transaction } \\
\text { price is } 2300 \text { yuan } / \mathrm{m}^{2} \text {, obviously lower than the lowest } \\
\text { transaction price determined after sampling the same } \\
\text { or similar housing estates with the estates involved in } \\
\text { the case. }\end{array}$ \\
\hline $\begin{array}{c}\text { Shaoguan } \\
\text { Yingjin Case } \\
\end{array}$ & $\begin{array}{c}20.52139 \text { thousand } \\
\text { yuan/m2 }\end{array}$ & $\begin{array}{c}10.018 \text { thousand } \\
\text { yuan } / \mathrm{m} 2\end{array}$ & $49.1 \%$ & $\begin{array}{l}\text { The taxpayer pays back taxes: This discount rate } \\
\text { doesn't follow the current market situation and } \\
\text { transaction practices of real estates, obviously lower. }\end{array}$ \\
\hline $\begin{array}{l}\text { Hepu Xiongying } \\
\text { Case } \\
\end{array}$ & 38.8733 million yuan & $\begin{array}{l}29.425691 \text { million } \\
\text { yuan }\end{array}$ & $75.7 \%$ & $\begin{array}{l}\text { The taxpayer pays back taxes: In comparison with the } \\
\text { taxable value re-certified by Pricing Certificating } \\
\text { Center and Local Tax Bureau, } 38.8733 \text { million yuan, } \\
\text { the transaction price is obviously lower. }\end{array}$ \\
\hline $\begin{array}{l}\text { Xiao Tianlong } \\
\text { Case }\end{array}$ & 0.773503 million yuan & 0.519 million yuan & $67.2 \%$ & $\begin{array}{l}\text { The taxpayer pays back taxes: The transaction } \\
\text { declared taxable price ratio is obviously lower than the } \\
\text { reference value generated by the tax assessment } \\
\text { system. }\end{array}$ \\
\hline $\begin{array}{l}\text { Zhou Jianqing, } \\
\text { Wang Tingxiang } \\
\text { Case }\end{array}$ & $\begin{array}{l}\text { the assessed value } \\
\text { approved by the tax } \\
\text { authority is } 2.758091 \\
\text { million yuan }\end{array}$ & 2.71 million yuan & $90.6 \%$ & $\begin{array}{c}\text { The taxpayer pays back taxes: The plaintiff's declared } \\
\text { tax price is } 2.5 \text { million yuan, greatly different from } \\
2.758091 \text { million yuan assessed by the tax authority, } \\
\text { obviously lower. }\end{array}$ \\
\hline $\begin{array}{l}\text { Yang Shuangzhen } \\
\text { Case }\end{array}$ & 1.08 million yuan & $\begin{array}{l}\text { Declared Taxable } \\
\text { Price : } 0.925 \text { million } \\
\text { yuan }\end{array}$ & $85.6 \%$ & $\begin{array}{l}\text { The taxpayer pays back taxes: The housing sales price } \\
\text { declared by the taxpayer is lower than the lowest } \\
\text { taxable price. Levying the tax based on the asserted } \\
\text { taxable price rather than false contract and under- } \\
\text { reporting sales price and other inaccurate declaration } \\
\text { of taxes. }\end{array}$ \\
\hline Minghua Case & $\begin{array}{l}11.46085 \text { thousand } \\
\text { yuan } / \mathrm{m} 2\end{array}$ & $\begin{array}{c}6.580 \text { thousand yuan } \\
\qquad / \mathrm{m}^{2}\end{array}$ & $57.4 \%$ & $\begin{array}{l}\text { The taxpayer has no needs to pay back taxes: The } \\
\text { second branch of Land Bureau violates the legal } \\
\text { procedure in the process of land appreciation tax } \\
\text { clearing in term of the project developed by the } \\
\text { plaintiff and its information on paying back taxes is } \\
\text { unsubstantiated and should be revoked lawfully. }\end{array}$ \\
\hline $\begin{array}{l}\text { Wang Weirong } \\
\text { Case } \\
\end{array}$ & 1.96 million yuan & 1.4 million yuan & $71.4 \%$ & $\begin{array}{l}\text { The taxpayer pays back taxes: The contract price of } \\
\text { the house is lower than the market appraisal. }\end{array}$ \\
\hline Gaoji, Wudi Case & 6.777749 million yuan & 4 million yuan & $59 \%$ & $\begin{array}{l}\text { The taxpayer pays back taxes: The price declared by } \\
\text { the plaintiff is obviously lower than that appraised by } \\
\text { Jiangsu Housing Transaction Tax Assessment System. }\end{array}$ \\
\hline
\end{tabular}

It can be discovered through the search on the three key words: tax administration law, being without due causes and being obviously low on the official site of Its law: there are totally 13 cases appearing from 2014 to 2017 where the tax authority considers the transaction price is obviously lower than the average market level without due causes and requires the taxpayers to pay back taxes according to the taxable amount assessed by the tax authority. These cases mainly appear in such developed areas as Shanghai, Jiangsu, Zhejiang and Guangdong in real estate transaction. The money involved in the real estate transaction in developed provinces and cities are of large amounts, which makes it inevitable for taxpayers to make all efforts to evade tax and tax bears to fight against tax avoidance at the same time.

Through the analysis of the statistics on "being obviously lower" in the cases, it is discovered: firstly, the phenomenon of tax evasion is serious. In these ten cases surveyed, there is phenomenon of false quotation among the taxpayers in many cases who declare the tax amount lower than the actual transaction price or even sign false contracts. The unclear definition of "being obviously lower" provides convenient conditions for their behaviors of tax avoidance; secondly, there are different basis of asserting "being obviously lower" in different cases by different tax authorities in different regions and the percentage of transaction price and average market transaction price ranges from $44 \%$ to $90.6 \%$. A lack of definition of "being obviously lower" causes a great gap between different tax authorities in the basis of asserting without unified standard of definition. Thereinto, in Zhou Jianqing case, Zhou Jianqing declares to the tax authority 2.5 million yuan in taxable price and the declared price account for $90.6 \%$ of average market transaction price, hardly to be passable in comparison with $44.3 \%$ in Guangzhou Defa case and $49.1 \%$ in Shaoguan Yingjin case and doesn't fit the audience's subjective judgement of the word "obvious". 


\section{Statistics And Analysis of "Being Without Due CAUSES" IN CASES}

In Tax Administrative Law, "being without due causes" and "being obviously lower" are connected with the word "and" in coordinative relation. As a legal element for the tax authority to assert the taxable price, "being without due causes" has wider discretionary power in the process of taxable price asserting, displaying more subjective color. In order to further learn the Court's judgement on "being without due causes", we carry out statistics on the judgement reasons of "being without due causes" in more than ten causes, shown in the following table 2-2:

TABLE II. Statistics on "Being Without Due Causes"

\begin{tabular}{|c|c|c|c|}
\hline Cases & $\begin{array}{l}\text { Reasons of Taxpayers' Lower } \\
\text { Declared Price }\end{array}$ & Assertion by the Tax Authority & Judgement Reason \\
\hline $\begin{array}{l}\text { Guangzhou } \\
\text { Defa Case }\end{array}$ & $\begin{array}{l}\text { Carrying a bank debt of } 130 \\
\text { million yuan }\end{array}$ & The reason is unjustifiable. & $\begin{array}{l}\text { The taxpayer pays back taxes: The deposit is set so high } \\
\text { that only one bids, causing the auction to be } \\
\text { uncompetitive. The transaction is concluded at a lower } \\
\text { reserve floor price which cannot reflect the market price } \\
\text { and obviously lower without unjustifiable reasons. }\end{array}$ \\
\hline $\begin{array}{l}\text { Shaoguan } \\
\text { Yingjin Case }\end{array}$ & $\begin{array}{l}\text { Sales promotion and capital } \\
\text { turnover }\end{array}$ & The reason is slender. & $\begin{array}{c}\text { The taxpayer pays back taxes: Yingjin Company fails to } \\
\text { provide evidences and reasonable explainations for a } \\
\text { sudden slash in the price of similar stores. }\end{array}$ \\
\hline $\begin{array}{l}\text { Hepu } \\
\text { Xiongying } \\
\text { Case } \\
\end{array}$ & $\begin{array}{l}\text { The tax authority's price asserting } \\
\text { procedure is illegal. }\end{array}$ & The reason is unjustifiable. & $\begin{array}{c}\text { The taxpayer pays back taxes: That the tax authority's } \\
\text { starting asserting procedure and authorizing the Pricing } \\
\text { Certificating Center of Hepu County in procedure is } \\
\text { asserted to be legal. }\end{array}$ \\
\hline $\begin{array}{l}\text { Xiao Tianlong } \\
\text { Case }\end{array}$ & $\begin{array}{l}\text { The amount asserted by the tax } \\
\text { authority doesn't fit that consulted } \\
\text { from the Deed Tax Collection } \\
\text { Window }\end{array}$ & The reason is unjustifiable. & $\begin{array}{l}\text { The taxpayer pays back taxes: Xiao Tianlong doesn't } \\
\text { express opposition after checking the information in } \\
\text { Deed Tax Declaration Form such as taxation basis and } \\
\text { pays back taxes, which belongs to giving up the rights } \\
\text { to state the justifiable reasons. }\end{array}$ \\
\hline $\begin{array}{l}\text { Sun Xiaobing } \\
\text { Case }\end{array}$ & $\begin{array}{l}\text { He should pay taxes according to } \\
\text { the transaction price in legal } \\
\text { mediation agreement. }\end{array}$ & $\begin{array}{l}\text { The declared transaction price: } \\
1.54 \text { million yuan and mediation } \\
\text { agreement should not be the } \\
\text { basis for price asserting. }\end{array}$ & $\begin{array}{c}\text { The taxpayer pays back taxes: He fails to present the } \\
\text { contract as the taxation basis, or declare again based on } \\
\text { this contract. The declared price is obviously lower } \\
\text { without justifiable reasons. }\end{array}$ \\
\hline $\begin{array}{l}\text { Zhou Jianqing, } \\
\text { Wang } \\
\text { Yanxiang Case }\end{array}$ & $\begin{array}{l}\text { It follows the market transaction } \\
\text { law. The current price of real } \\
\text { estates reduces. }\end{array}$ & $\begin{array}{l}\text { The declared transaction price: } \\
2.5 \text { million yuan with } \\
\text { unjustifiable reasons. }\end{array}$ & $\begin{array}{l}\text { The taxpayer pays back taxes: There are situations of } \\
\text { many transaction contracts and prices, hiding the truth. }\end{array}$ \\
\hline $\begin{array}{l}\text { Yang } \\
\text { Shuangzhen } \\
\text { Case }\end{array}$ & $\begin{array}{l}\text { The agreed transfer price in the } \\
\text { contract is } 925 \text { thousand yuan. }\end{array}$ & The reasons are unjustifiable. & $\begin{array}{l}\text { The taxpayer pays back taxes: It is found out that the } \\
\text { actual income of the plaintiff through transfer is } \\
116.77112 \text { thousand yuan and the displayed transaction } \\
\text { price in the contract is false. The declared price is } \\
\text { obviously lower without justifiable reasons. }\end{array}$ \\
\hline Minghua Case & $\begin{array}{l}\text { Sales promotion makes up for } \\
\text { insufficient fund, the low price } \\
\text { fits the situation of low-quality } \\
\text { supporting facility. The real estate } \\
\text { transaction happens during } 2008 \\
\text { and } 2009 \text { and should not take the } \\
\text { average market price of } 2011 \text { as } \\
\text { the taxation basis. }\end{array}$ & $\begin{array}{l}\text { The fact of being obviously } \\
\text { lower is clear, for which the } \\
\text { reasons provided by Minghua } \\
\text { Company are unjustifiable. }\end{array}$ & $\begin{array}{l}\text { The taxpayer pays back taxes: The tax authority fails to } \\
\text { show in the clearing process whether to check the } \\
\text { plaintiff's land status, oceanside location, green } \\
\text { landscape and plot ratio in the project in person or } \\
\text { through entrusting, so the price asserting work can not } \\
\text { be proved and the tax authority's procedure of asserting } \\
\text { the plaintiff's project price is illegal. }\end{array}$ \\
\hline $\begin{array}{l}\text { Wang Weirong } \\
\text { Case }\end{array}$ & $\begin{array}{l}\text { The actual expression of the two } \\
\text { parties' intention without avoiding } \\
\text { tax liabilities. }\end{array}$ & The reasons are unjustifiable. & $\begin{array}{l}\text { The taxpayer pays back taxes: The market valuation of } \\
\text { the real estate on Hutai Road on January, } 2016 \text { is higher } \\
\text { than the agreed price, which belongs to the transaction } \\
\text { risks the plaintiff should foreknow when purchasing the } \\
\text { settlement buildings. The declared price is obviously } \\
\text { lower without justifiable reasons. }\end{array}$ \\
\hline $\begin{array}{l}\text { Gaoji, Wudi } \\
\text { Case }\end{array}$ & $\begin{array}{l}\text { The house appears such loss } \\
\text { situations as subsurface filtration. } \\
\text { The tax authority fails to appraise } \\
\text { the current situation of the house } \\
\text { and the asserted price is too high. }\end{array}$ & $\begin{array}{l}\text { The plaintiff fails to put forward } \\
\text { tax price controversy handling } \\
\text { procedure and the taxpayer's } \\
\text { reasons are sufficient. }\end{array}$ & $\begin{array}{l}\text { The taxpayer pays back taxes: The plaintiff fails to } \\
\text { apply to the defendant for controversy handling in the } \\
\text { process of tax declaration and require to assert the } \\
\text { taxation price again, and there is no trace of the } \\
\text { plaintiff's declaring lower price with reasonable reasons } \\
\text { from the current evidences. }\end{array}$ \\
\hline
\end{tabular}

According to the statistical results in table 1-2, it is discovered that: firstly, the problem of information asymmetry between tax authorities and taxpayers exists everywhere, for example, in Minghua case, the actual real estate transaction occurred during 2008 and 2009, but the tax authority carried out assertion based on the market transaction price of 2011. The existence of information asymmetry between the two parties will greatly increase the cost of tax collection and waste the administrative resources; secondly, the question of evidence is another problem. The law provides taxpayers relief approaches and when taxpayers consider the taxable value asserted by the tax authority unreasonable, they should provide evidences to express the opposition on the price asserted by the tax authority while the tax authority should further adjust the 
taxable value after asserting of the evidences provided. However, according to the statistical results above mentioned, the tax authority will always consider the evidences taxpayers provide unjustifiable no matter which reasons taxpayers provide to prove their declared price is of rationality. In Minghua case, the tax authority's assertion of taxable value indeed misuses the law and it is illegal in procedure, but in addition to that the Court judges Minghua Company to have no needs to pay back taxes, other judgement made by the Court is consistent with that of the tax authority, then the relief approaches have no existing significance; thirdly, at present, the competent tax departments under the State Council have not made clear definition of the specific procedure and method of tax payable assertion. Taxpayers know nothing about how the final taxable value is asserted, which hides dangers for tax authorities' misusing discretionary power. Among the cases above mentioned, Minghua case is the only one where the tax authority loses a lawsuit where we can discover there is indeed phenomenon that the tax authority abuses their power in the process of tax collection which considers the declared tax amount obviously lower without field verification of the land status, Oceanside location and other situations of the project, damaging the credibility of tax authorities.

\section{Suggestions ON PERFECTING SUbPRAgRAPH 1(6)OF ARTICLE 35 OF TAX ADMINISTRATION LAW}

\section{A. Learning From Interpretation II on Contract Law in Legislation}

The article 19 of Interpretation II on Contract Law makes relevant definition on "being obviously lower". We can absorb the essence involved and core to improve the situation of there being no definition of "being obvious lower" in article subparagraph 1(6) of Tax Administration Law. There are four core concepts worthy of being learned from in article 19 of Interpretation II on Contract Law: firstly, the consideration of price should be based on the judgement of the local managers and the administrative department should establish notification, hearing, debating and avoiding publicity system by targeting at the modes and reasons of valuation asserting to protect the citizens' property interest; secondly, tax authorities should make clear definition of "same land", "similar" and "meanwhile" and so on in their concept and reference number when asserting the taxable value no matter by manual approach or tax assessment system; thirdly, to comprehensively appraise and assert the taxable value by combining with such factors as actual transaction of different commodities. It is necessary to not only take the average market transaction price of this kind of commodities in a same place within a certain time into consideration to carry out price evaluation, but also take the quality and loss of the commodity itself into consideration to achieve specific analysis of specific issues; fourthly, Interpretation II on Contract Law specifies the transaction price should not be below $70 \%$ of average market transaction price, achieving a subjective and standard grasp of the indefinite concept.

\section{B. Setting Up the Third-party Authority for Evidence Verification}

As the subject of tax collection and payment respectively, tax authorities and taxpayers are in dispute inevitably when the former is in its law enforcement process. It is unavoidable for indefinite legal concept to exist in real life, and the key lies on the means and attitudes to deal with them. Tax authorities should set up the third-party organization to verify the evidences and make clear definition on the subject and procedure of verification to ensure its fairness. When taxpayers consider the taxable value asserted by the tax authority unreasonable and provide evidences to prove it, these evidences should be verified and determined by the third-party organization according to the legal procedures. If the thirdparty organization considers the evidences the taxpayers provide reasonable, it has the right to require the tax authority to assert the taxable value again. When the tax authority considers the taxable value declared by the taxpayers obviously lower without justifiable reasons, it should legally collect relevant evidences to prove the taxpayers' transaction price is obviously lower without justifiable reasons and the evidences should be assessed and verified by the third-party organization to decentralize the power of tax authorities and avoid too much discretionary power of tax authorities.

\section{CONCLUSION}

As clear judgement standards of "being obviously lower" and "being without justifiable reasons" are lacked, it indeed presents challenges to tax authorities in both law enforcement and judicial practices. Therefore, to perfect Tax Administration Law, it is available to borrow from the relevant regulations of Interpretation II on Contract Law and provide subjective legal judgement standards for "being obviously lower" and "being without justifiable reasons" by legislation, making clear definition on the procedure of tax authorities' asserting the taxable value and making the principles of law-based taxation go through Tax Administration Law. Of course, under the condition of imperfect law, tax authorities should actively explore scientific ways of law enforcement and the state should set up the third-party organization to reasonably solve the conflicts of evidences with the taxpayers to avoid having too much discretionary power so as to promote the perfection of Taxation Law.

\section{REFERENCES}

[1] Liu Songshan. Strategies of Contemporary China in Dealing with the Relationships between Legislation and Reform [J].Jurisprudence, 2014(01):74-92.

[2] Xu Duoqi. The Effective Approach to Implement Principle of Lawbased Taxation--Establishing Chinese Taxpayers' Right Protection Officer System[J].Legal Forum, 2014,29(04):54-61.

[3] Zhai Jiguang. Discussion on Judgement Standards of "Taxation Basis" Being Obviously Lower Without Justifiable Reasons" [J]. Taxation Research, 2016(08):56-59.

[4] Deng Huimin, Discussion on Tax Authorities' Asserting and Levying Power [J]. Economy and Trade Practices, 2017(22):255.

[5] Zhu Changsheng. The Application of "Taxation Basis' Being Obviously Lower Without Justifiable Reasons" in Practice [J]. Taxation Research, 2017(09):96-100.

[6] Fan Ziying, Tian Binbin. Tax Competition, Tax Law Enforcement and Corporate Tax Avoidance [J]. Economic Research, 2013, 48(09):99-111. 